\title{
Correlating microscopic findings with B-mode ultrasound in cervical artery dissection
}

Figure $1 \quad$ B-mode ultrasound, right common carotid artery (longitudinal section)

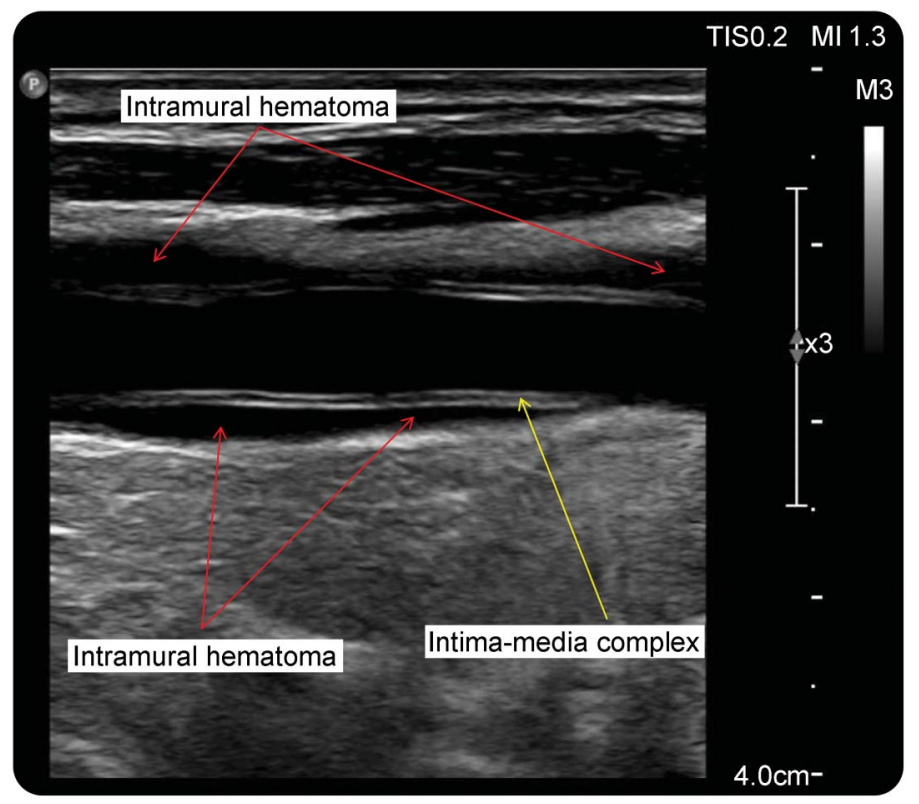

The red arrows show the intramural hematoma; the yellow arrow marks the intima-media complex, which is intact.

Figure 2 B-mode ultrasound, right common carotid artery (cross-section)

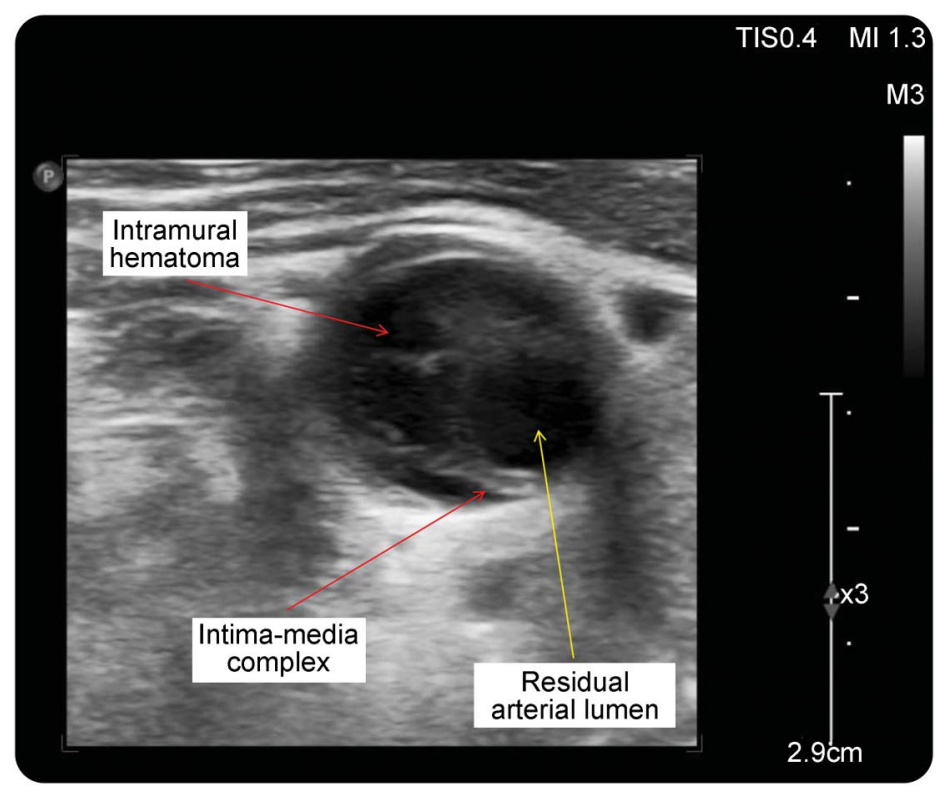

Cross-section shows the half-moon-shaped hematoma, narrowing the arterial lumen. 
In a previous study, microscopic findings in superficial temporal artery specimens in patients with cervical artery dissections suggest that the pathophysiologic mechanism is an expanding hematoma in the medialadventitial border arising from the vasa vasorum. ${ }^{1}$ The hematoma is half-moon-shaped and can be visualized by T1-weighted fat-saturated MRI. ${ }^{2}$

I report a 57-year-old patient with dissection of the truncus brachiocephalicus and involvement of the right common and internal carotid arteries. In this case, the intramural hematoma was visible by B-mode ultrasound (figures 1 and 2) and supports the assumption of medio-adventitial bleeding, since the intima-media complex is unaffected.

\section{Ralf Dittrich, $M D$}

From the Department of Neurology of the University Hospital of Muenster, Germany.

Study funding: No targeted funding reported.

Disclosure: R. Dittrich reports no disclosures relevant to the manuscript. Go to Neurology.org for full disclosures.

Correspondence to Dr. Dittrich: Ralf.Dittrich@ukmuenster.de

1. Völker W, Dittrich R, Grewe S, et al. The outer arterial wall layers are primarily affected in spontaneous cervical artery dissection. Neurology 2011;76:1463-1471.

2. Flis CM, Jager HR, Sidhu PS. Carotid and vertebral artery dissections: clinical aspects, imaging features and endovascular treatment. Eur Radiol 2007;17:820-834.

\section{WriteClick ${ }^{\circledR}$ rapid online correspondence}

Have a comment on a recent $N e u r o l o g y{ }^{\circledR}$ article you would like to share? Now it is easier and more convenient. Neurology.org has launched WriteClick on the home page and sidebars of each article to encourage remarks and debate among users.

WriteClick is restricted to comments about studies published in Neurology within the last eight weeks.

Learn more at Neurology.org/letters

\section{Save These Dates for AAN CME Opportunities!}

Mark these dates on your calendar for exciting continuing education conferences by the American Academy of Neurology. Learn more at AAN.com/conferences.

\section{Sports Concussion Conference}

- July 14-16, 2017, Jacksonville, FL, at the Hyatt Regency Jacksonville Riverfront

\section{AAN Fall Conference}

- October 20-22, 2017, Las Vegas, NV, at The Cosmopolitan of Las Vegas

Breakthroughs in Neurology Conference

- January 12-15, 2018, Orlando, FL, at the Caribe Royale Orlando 


\section{Neurology}

Correlating microscopic findings with B-mode ultrasound in cervical artery dissection Ralf Dittrich

Neurology 2017;88;2236-2237

DOI 10.1212/WNL.0000000000004013

This information is current as of June 5, 2017

\begin{tabular}{|c|c|}
\hline $\begin{array}{l}\text { Updated Information \& } \\
\text { Services }\end{array}$ & $\begin{array}{l}\text { including high resolution figures, can be found at: } \\
\text { http://n.neurology.org/content } / 88 / 23 / 2236 \text {. full }\end{array}$ \\
\hline References & $\begin{array}{l}\text { This article cites } 2 \text { articles, } 1 \text { of which you can access for free at: } \\
\text { http://n.neurology.org/content/88/23/2236.full\#ref-list- } 1\end{array}$ \\
\hline Subspecialty Collections & $\begin{array}{l}\text { This article, along with others on similar topics, appears in the } \\
\text { following collection(s): } \\
\text { All Clinical Neurology } \\
\text { http://n.neurology.org/cgi/collection/all_clinical_neurology } \\
\text { Carotid artery dissection } \\
\text { http://n.neurology.org/cgi/collection/carotid_artery_dissection } \\
\text { Ultrasound } \\
\text { http://n.neurology.org/cgi/collection/ultrasound }\end{array}$ \\
\hline Permissions \& Licensing & $\begin{array}{l}\text { Information about reproducing this article in parts (figures,tables) or in } \\
\text { its entirety can be found online at: } \\
\text { http://www.neurology.org/about/about_the_journal\#permissions }\end{array}$ \\
\hline Reprints & $\begin{array}{l}\text { Information about ordering reprints can be found online: } \\
\text { http://n.neurology.org/subscribers/advertise }\end{array}$ \\
\hline
\end{tabular}

Neurology ${ }^{\circledR}$ is the official journal of the American Academy of Neurology. Published continuously since 1951, it is now a weekly with 48 issues per year. Copyright @ 2017 American Academy of Neurology. All rights reserved. Print ISSN: 0028-3878. Online ISSN: 1526-632X.

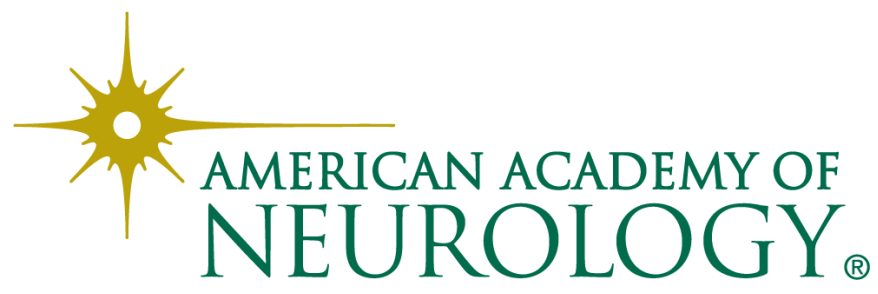

